\title{
Study on serum magnesium levels and glycemic status in newly detected type 2 diabetes patients
}

\author{
Senthil Manikandan Thirumanilayur Jayaraman ${ }^{1}$, Kannan Rajendran ${ }^{1}$, \\ Prasanna Karthik Suthakaran ${ }^{1}$, Lal Devayani Vasudevan Nair ${ }^{2}$, Lokesh Rajaram ${ }^{3}$, \\ Rajiv Gnanasekar ${ }^{4}$, Rajendran Karuthodiyil ${ }^{1}$
}

\author{
${ }^{1}$ Department of General Medicine, Saveetha Medical College Hospital, Chennai, Tamilnadu, India \\ ${ }^{2}$ Department of Paediatrics, Saveetha Medical College Hospital, Chennai, Tamilnadu, India \\ ${ }^{3}$ Department of General Medicine, Ulundai PHC, Cheyyar Health Unit District, Tiruvannamalai, Tamilnadu, India \\ ${ }^{4}$ Department of Anaesthesia, Jawaharlal Institute of Postgraduate Medical Education and Research, Pondicherry, India
}

Received: 2 November 2015

Accepted: 17 November 2015

\author{
*Correspondence: \\ Dr. Kannan Rajendran, \\ E-mail: endork@yahoo.com
}

Copyright: (C) the author(s), publisher and licensee Medip Academy. This is an open-access article distributed under the terms of the Creative Commons Attribution Non-Commercial License, which permits unrestricted non-commercial use, distribution, and reproduction in any medium, provided the original work is properly cited.

\begin{abstract}
Background: Hypomagnesaemia is known to occur among patients with type 2 diabetes compared with those who are non-diabetics. It has been linked to the development of diabetes mellitus as well as poor glycemic control. Our objective was to assess the levels of serum magnesium among newly diagnosed type 2 diabetes patients and its correlation with their glycemic status.

Methods: 42 newly diagnosed type 2 diabetic patients without any micro or macro vascular complications were selected, divided into two groups $(\mathrm{n}=21)$, Group 1 diabetics $-\mathrm{HbA1c}<7.0 \%$ and Group 2 diabetics $-\mathrm{HbA1c}>7.0 \%$. Serum levels of magnesium and HbA1C values were measured and analysed.

Results: Hypomagnesaemia was present in both controlled and uncontrolled diabetics groups. Even though low magnesium levels were noted even at the time of diagnosis, Group 2 had significantly lower values when compared to Group 1 [0.7267 \pm 0.2114 vs $1.9862 \pm 0.329$, P $<0.0001]$. Serum magnesium level was inversely correlated to glycemic control which was statistically significant $[\mathrm{r}=-0.8647, \mathrm{P}<0.00001]$.

Conclusions: Serum magnesium levels were low at the time of diagnosis of diabetes in our study. As the age of the study population increased, serum magnesium levels also varied but the changes were not statistically significant. Serum levels of magnesium were lower even before the onset of diabetic micro and macro vascular complications. Large scale studies are needed to confirm this observation so that serum magnesium levels can be used as a potential indicator of risk of development of diabetic complications.
\end{abstract}

Keywords: Type 2 Diabetes mellitus, Glycosylated haemoglobin, HbA1c, Magnesium, Hypomagnesaemia

\section{INTRODUCTION}

Magnesium is the second most abundant intracellular cation in the body. It plays a significant role in many metabolic pathways, especially in glucose metabolism, by acting as a cofactor for several enzymes. It plays a vital role in insulin secretion, insulin binding and homeostasis. ${ }^{1}$ Low levels of magnesium have shown to damage tyrosine kinase activity and receptors involved in signaling. ${ }^{2}$ Both intracellular and extracellular magnesium deficits are associated with type 2 diabetes mellitus. ${ }^{3}$ Hypomagnesemia has been implicated in carbohydrate intolerance, hyperglycaemia, insulin resistance, complications of diabetes and hyperlipidemia. ${ }^{4}$ Hypomagnesemia is common among diabetic patients which is frequently underdiagnosed. It is now established 
that diabetes can by itself induce hypomagnesemia and hypomagnesemia can in turn induce onset or worsen diabetes mellitus. ${ }^{4}$ Many studies have reported significantly lower serum magnesium levels in type 2 diabetics when compared with non-diabetic healthy controls. $^{5}$ Among diabetics, low serum magnesium values were reported in patients with retinopathy. ${ }^{6}$ Magnesium deficiency may be an independent risk factor for the development of hyperglycemia. ${ }^{4}$ Systemic inflammation and insulin resistance are the important reasons for the inverse relationship of magnesium intake and diabetes mellitus. ${ }^{1}$

Even though low plasma magnesium levels have been found and reported in many studies from various countries, there are very few reports from our part of the country. ${ }^{1,5,6}$ Also, the comparative studies within diabetic population based on glycemic control are limited. With this background, we decided to study the level of serum magnesium in newly diagnosed type -2 diabetics without micro vascular complications and correlate with glycemic status.

\section{METHODS}

\section{Study design and patient selection}

The study was designed as a hospital based, cross sectional, comparative study for assessment of serum magnesium levels in newly diagnosed type 2 diabetic patients without any micro or macrovascular complications, recruited from the diabetic outpatient clinic of a tertiary care medical college hospital of South India.

The study included uncomplicated diabetic patients of age between 30 to 60 years. Patients with pre-diabetes, diabetics with microvascular or macrovascular complications, renal failure, hepatic failure, cardiac failure, thyroid disorders, alcoholics, lactating and pregnant females and those who were treated with magnesium supplements, Tetracycline's, Cisplatin, Quinolones, Amiloride, ACE Inhibitors and Thiazide diuretics were excluded. In order to detect a statistically significant difference between the two groups with a $95 \%$ confidence interval and to ensure a minimum power of at least $80 \%$, the population sample was calculated to be at least 19 in each group. Due permission was obtained from Institutional Research Board and Institutional Ethics Committee before the start of the study. A total of 468 newly diagnosed diabetics were found to be eligible for the study during the study period, out of which 226 diabetics who were found to have $\mathrm{HbA} 1 \mathrm{c}<7.0 \%$ were assigned to Group 1 while 242 patients who had HbA1c > $7.0 \%$ were assigned to Group 2. In order to eliminate selection bias, the patients were selected by systematic random sampling such that every $10^{\text {th }}$ patient was recruited in to the study.
All the selected patients were invited to take part in the study. Detailed patient information sheet was provided and the investigators explained the study details to the patients. Willing patients were requested to give their written informed consent. One patient in Group 1 and three patients in Group 2 were not willing to provide informed consent. Therefore, the study groups consisted of 21 patients each.

$5 \mathrm{ml}$ blood sample was collected, irrespective of the last meal, in a trace element free vacutainer tube and was centrifuged at $2000 \mathrm{rpm}$ to separate the serum. Serum magnesium levels were estimated using Inductively Coupled Plasma - Optical Emission Spectrophotometer (ICP - OES). ICP - OES which was used for magnesium estimation is more specific in comparison with Atomic Absorption Spectrometry which was utilized in most of the previously done studies. It also minimized the blood requirement for estimation.

\section{Statistical analysis}

The result from ICP - OES was expressed as Mean \pm SD. Data was compared between the two groups using appropriate parametric tests by SPSS for Windows statistical software version 20 .

\section{RESULTS}

Among the patients who participated in our study, 62\% were males and $38 \%$ of them were females. Patients with HbA1c $<7.0 \%$ were assigned to Group 1 while patients who had HbA1c $>7.0 \%$ were assigned to Group 2 .

Table 1: Baseline characteristics and serum magnesium of the study population.

\begin{tabular}{|c|c|c|c|c|c|}
\hline & \multicolumn{2}{|c|}{$\begin{array}{l}\text { Group } 1 \\
(\text { HbA1c }< \\
\mathbf{7 . 0 \%})\end{array}$} & \multicolumn{2}{|c|}{$\begin{array}{l}\text { Group } 2 \\
(\text { HbA1c > } \\
7.0 \%)\end{array}$} & \multirow[t]{2}{*}{$\begin{array}{l}\mathbf{P} \\
\text { Value }\end{array}$} \\
\hline & Mean & $\begin{array}{l}95 \% \\
\text { CI }\end{array}$ & Mean & $\begin{array}{l}95 \% \\
\mathrm{CI}\end{array}$ & \\
\hline $\begin{array}{l}\text { Age } \\
\text { (In years) }\end{array}$ & 47.52 & $\begin{array}{l}43.78- \\
51.26\end{array}$ & 47.95 & $\begin{array}{l}44.8- \\
51.05\end{array}$ & 0.8550 \\
\hline $\operatorname{Sex}(M / F)$ & $14 / 7$ & & $12 / 9$ & & \\
\hline $\begin{array}{l}\text { Mean } \mathrm{HbA} 1 \mathrm{c} \\
(\%)\end{array}$ & 6.59 & $\begin{array}{l}6.47- \\
6.71\end{array}$ & 10.23 & $\begin{array}{l}9.49- \\
10.97\end{array}$ & $<0.0001$ \\
\hline $\begin{array}{l}\text { Serum } \\
\text { magnesium } \\
(\mathrm{mg} / \mathrm{dL})\end{array}$ & 1.99 & $\begin{array}{l}1.84- \\
2.14\end{array}$ & 0.73 & $\begin{array}{l}0.63- \\
0.83\end{array}$ & $<0.0001$ \\
\hline
\end{tabular}

In Group 1, 66\% were males and 34\% were females whereas in Group 2, 57\% were males and $43 \%$ were females. The mean age of participants of group 1 was $47.52 \pm 8.22$ and of group 2 was $47.95 \pm 6.82$, which was comparable and not statistically significant $(\mathrm{P}=0.855)$. Mean HbA1c level of the two groups was estimated and the difference was found to be statistically significant $(6.59 \pm 0.266$ vs. $10.233 \pm 1.623, \mathrm{P}<0.0001)$. 
Table 2: Mean serum magnesium concentrations according to the sex distribution.

\begin{tabular}{|c|c|c|c|c|c|}
\hline \multirow{2}{*}{$\begin{array}{l}\text { Mean } \\
\text { Serum } \\
\text { Magnesium } \\
\text { (mg/dL) }\end{array}$} & \multicolumn{2}{|c|}{$\begin{array}{l}\text { Group } 1 \\
(\text { HbA1c < } \\
7.0 \%)\end{array}$} & \multicolumn{2}{|c|}{$\begin{array}{l}\text { Group } 2 \\
(\text { HbA1c }> \\
7.0 \%)\end{array}$} & \multirow{2}{*}{$\begin{array}{l}\mathbf{P} \\
\text { Value }\end{array}$} \\
\hline & Mean & $\begin{array}{l}95 \% \\
\text { CI }\end{array}$ & Mean & $\begin{array}{l}95 \% \\
\text { CI }\end{array}$ & \\
\hline Males & 2.02 & $\begin{array}{l}1.81- \\
2.23\end{array}$ & 0.73 & $\begin{array}{l}0.60- \\
0.86\end{array}$ & $\begin{array}{l}< \\
0.0001\end{array}$ \\
\hline Females & 1.93 & $\begin{array}{l}1.66- \\
2.20\end{array}$ & 0.72 & $\begin{array}{l}0.54- \\
0.90\end{array}$ & $\begin{array}{l}< \\
0.0001\end{array}$ \\
\hline
\end{tabular}

Group 1 had higher levels of serum magnesium when compared to Group 2 and the difference was statistically significant $(\mathrm{P}<0.0001)$ (Table 1). This difference was maintained across age groups and as well as in the sex distribution in both the groups (Table 2, 3). However, there was no relation between the age group or sex of the patient and the serum magnesium levels in our study.

Regression analysis revealed a significant inverse relationship between serum magnesium levels and HbA1c values $(r=-0.8647, P<0.00001)$ (Figure 1$)$.

Table 3: Mean serum magnesium concentrations according to the age distribution.

\begin{tabular}{|c|c|c|c|c|c|}
\hline \multirow{2}{*}{$\begin{array}{l}\text { Mean } \\
\text { Serum } \\
\text { Magnesium } \\
\text { (mg/dL) }\end{array}$} & \multicolumn{2}{|c|}{$\begin{array}{l}\text { Group } 1 \\
(\text { HbA1c < } \\
7.0 \%)\end{array}$} & \multicolumn{2}{|c|}{$\begin{array}{l}\text { Group } 2 \\
(\text { HbA1c > } \\
7.0 \%)\end{array}$} & \multirow{2}{*}{$\begin{array}{l}\mathbf{P} \\
\text { Value }\end{array}$} \\
\hline & Mean & $\begin{array}{l}95 \% \\
\mathrm{CI}\end{array}$ & Mean & $\begin{array}{l}95 \% \\
\text { CI }\end{array}$ & \\
\hline $\begin{array}{l}31-40 \\
\text { years }\end{array}$ & $\begin{array}{l}1.85 \pm \\
0.14\end{array}$ & $\begin{array}{l}1.70- \\
2.00\end{array}$ & $\begin{array}{l}0.76 \pm \\
0.30\end{array}$ & $\begin{array}{l}0.39 \\
-1.13\end{array}$ & $<0.0001$ \\
\hline $\begin{array}{l}41-50 \\
\text { years }\end{array}$ & $\begin{array}{l}2.14 \pm \\
0.44\end{array}$ & $\begin{array}{l}1.73- \\
2.55\end{array}$ & $\begin{array}{l}0.71 \pm \\
0.21\end{array}$ & $\begin{array}{l}0.57- \\
0.85\end{array}$ & $<0.0001$ \\
\hline $\begin{array}{l}51-60 \\
\text { years }\end{array}$ & $\begin{array}{l}1.95 \pm \\
0.30\end{array}$ & $\begin{array}{l}1.70- \\
2.20\end{array}$ & $\begin{array}{l}0.74 \pm \\
0.19\end{array}$ & $\begin{array}{l}0.54- \\
0.94\end{array}$ & $<0.0001$ \\
\hline
\end{tabular}

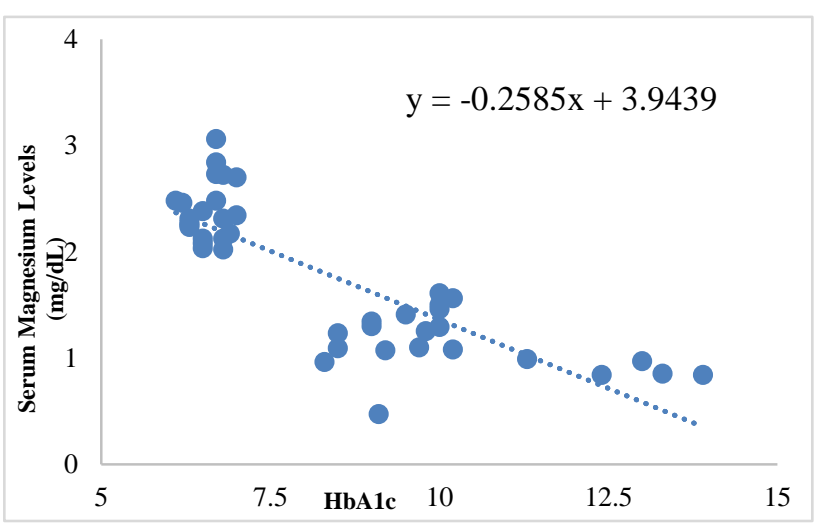

Figure 1: Correlation between serum magnesium levels and hba1c values.

\section{DISCUSSION}

Magnesium is clinically used to treat eclampsia, preeclampsia, constipation, status asthmaticus, alcohol withdrawal, torsade de pointes and provides symptomatic relief in migraine and dyspepsia. It was investigated for treating leg cramps in pregnant women and prevention of osteoporosis. ${ }^{7}$ Recent research links magnesium deficiency with diabetic nephropathy, aging and cognitive decline. ${ }^{2}$ High magnesium intake has been proven to be beneficial in conditions like dyslipidaemia, metabolic syndrome, coronary artery diseases and hypertension. ${ }^{8}$ It is of use in diabetic ketoacidosis as a deficit of 1 to $2 \mathrm{meq} / \mathrm{L}$ of magnesium is seen in diabetic ketoacidosis and magnesium replacement in such documented cases has improved the outcomes. ${ }^{9}$

In this study, we observed low levels of magnesium in group 2 where HbA1c was above $7 \%$ when compared to group 1 where HbA1c was less than $7 \%$. Sharma et al observed that those who had low serum magnesium levels were prone for diabetes related complications (hypertension, dyslipidaemia, and retinopathy). The study also showed lower levels in diabetics when compared to healthy controls. ${ }^{10}$ Diwan et al had made similar observations about magnesium. ${ }^{11}$ Kareem et al found low serum magnesium level in diabetic patients and that the level was lowest in patients with retinopathy. They also demonstrated an inverse relationship between magnesium level and glycemic control which was similar to the relationship established in our study. ${ }^{6}$

Walti et al showed low magnesium status among type 2 diabetics and suggested periodic monitoring of magnesium levels is necessary to prevent secondary complications. ${ }^{1}$ Coronary Artery Risk Development in Young Adults (CARDIA), a longitudinal study of American adult population, again found an inverse association between magnesium intake and diabetes risk. $^{12}$ Wang et al found that the dietary intake of magnesium was inadequate even in non diabetics with metabolic syndrome and by increasing the dietary intake, it is possible to protect against the development of insulin resistance in such cases. ${ }^{13}$ There was a significant difference in magnesium levels in newly diagnosed uncontrolled diabetics and well controlled diabetics in our study. This difference may be used as a potential predictor for the onset of microangiopathies, similar to the findings of Kundu et al who concluded that low magnesium levels were observed in diabetic patients and it can be used as a marker to predict retinopathy. ${ }^{14}$

As observed in multiple studies, the present study also revealed low magnesium levels with increasing age and in female diabetics. ${ }^{6,15}$ The causes of low magnesium levels in diabetes are still debated and it may due to an increased urinary loss of magnesium due to the osmotic action of glycosuria along with decreased tubular reabsorption of magnesium due to hyperglycemia. ${ }^{16}$ 
In a recent meta-analysis published by Dong et al, the authors observed an inverse association between magnesium intake and risk of type 2 diabetes. ${ }^{17}$ Though few Indian studies have studied the role of magnesium supplementation in diabetics, more large scales studies from India would help to decide about the dosage and side effects encountered in our population. Current recommendations for dietary intake of magnesium are based on the studies done abroad and extrapolated to the Indian population. ${ }^{18,19}$

We compared the levels of magnesium in newly diagnosed controlled and uncontrolled diabetes patients, which was not done in previous studies. Most studies compared diabetic subjects with healthy non diabetic subjects, but we decided both our groups will be diabetics for better understanding. The limitations of our study were its small sample size, exclusion of complicated cases, absence of normal controls and non-inclusion of dietary patterns.

\section{CONCLUSIONS}

Magnesium deficiency is present at the time of diagnosis in newly diagnosed diabetic patients who have higher levels of HbA1c. As the age of the study population increased, serum magnesium levels also varies. Levels of magnesium drop with increasing glucose levels, much more before the onset of diabetic micro and macro vascular complications. This can be used as a marker to assess the risk of complication even at the first encounter with diabetic patients as values correlates with $\mathrm{HbA1c}$ levels. It may be worthwhile to screen newly diagnosed Indian diabetic patient for hypomagnesaemia.

Funding: No funding sources

Conflict of interest: None declared

Ethical approval: The study was approved by the Institutional Ethics Committee

\section{REFERENCES}

1. Wälti MK, Zimmermann MB, Spinas GA, Hurrell RF. Low plasma magnesium in type 2 diabetes. Swiss Med Wkly. 2003;133(19-20):289-92.

2. Sales CH, Pedrosa L de F. Magnesium and diabetes mellitus: their relation. Clinical Nutrition. 2006;25:554-62.

3. Barbagallo M, Dominguez LJ. Magnesium and type 2 diabetes World J Diab. 2015;6(10):1152-7.

4. Pham PC, Pham PM, Pham SV, Miller JM, Pham $\mathrm{PT}$. Hypomagnesemia in patients with type 2 diabetes. Clin J Am Soc Nephrol. 2007;2(2):366-73.

5. Ranjith Kumar GK, Santhosh P. Study of Serum Magnesium Levels in Type 2 Diabetics. Int J Med Res Rev. 2015;3(7):699-705.

6. Kareem I, Jaweed SA, Bardapurkar JS, Patil VP. Study of magnesium, glycosylated hemoglobin and lipid profile in diabetic retinopathy. Ind $\mathrm{J}$ Clin Biochem. 2004;19(2):124-7.

7. Guerrera MP, Volpe SL, Mao JJ. Therapeutic Uses of Magnesium. Am Fam Phys. 2009;80(2):157-62.

8. $\mathrm{Ka} \mathrm{He}$, Kiang Liu, Daviglus ML, Morris SJ, Loria CM, Van Horn L et al. Magnesium Intake and Incidence of Metabolic Syndrome among Young Adults. Circulation. 2006;113:1675-82.

9. Trachtenbarg DE. Diabetic ketoacidosis. Am Fam Phys. 2005;71(9):1705-14.

10. Sharma A, Dabla S, Agrawal RP, Barjatya H, Kochar DK, Kothari RP. Serum magnesium: an early predictor of course and complications of diabetes mellitus. J IndMed Assoc. 2007;105(1):168,20 .

11. Diwan AG, Pradham AB, Lingojwar D, Krishna KK, Singh P, Almelkar SL. Serum zinc, chromium and magnesium levels in type 2 diabetes. Int J Diab Dev Ctries. 2006;26(3):122-3.

12. Kim DJ, Xun P, Liu K, Loria C, Yokota K, Jacobs $\mathrm{DR}$, et al. Magnesium Intake in Relation to Systemic Inflammation, Insulin Resistance, and the Incidence of Diabetes. Diabetes Care. 2010;33(12):2604-10.

13. Wang J, Persuitte G, Barbara C, Olendzki et al. Dietary Magnesium Intake Improves Insulin Resistance among Non-Diabetic Individuals with Metabolic Syndrome Participating in a Dietary Trial. Nutrients. 2013;5(10):3910-9.

14. Kundu D, Osta M, Mandal T, Bandyopadhyay U, Ray D, Gautam D. Serum magnesium levels in patients with diabetic retinopathy. J Nat Sci Biol Med. 2013;4(1):113-6

15. Barbagallo $M$, Dominguez LJ. Magnesium and aging. Curr Pharm Des. 2010;16(7):832-9.

16. Guerrera MP, Volpe SL, Mao JJ. Therapeutic Uses of Magnesium. Am Fam Physician. 2009;80(2):15762.

17. Dong J, Xue P, He K, Li-Quang quin. Magnesium Intake and Risk of Type 2 Diabetes: Meta-analysis of prospective cohort studies. Diabetes Care. 2011;34(9):2116-22.

18. Rodríguez MM, Romero GF. Oral magnesium supplementation improves insulin sensitivity and metabolic control in type 2 diabetic subjects: a randomized double-blind controlled trial. Diabetes Care. 2003;26:1147-52.

19. Lal J, Vasudev K, Kela AK, Jain SK. Effect of oral magnesium supplementation on the lipid profile and blood glucose of patients with type 2 diabetes mellitus. J Assoc Phys Ind. 2003;51:37-42.

Cite this article as: Senthil Manikandan TJ, Kannan R, Prasanna Karthik S, Lal DV, Lokesh R, Rajiv G, Rajendran K. Study on serum magnesium levels and glycemic status in newly detected type 2 diabetes patients. Int J Adv Med 2016;3:11-4. 